\title{
Needs Analysis of Saudi EFL Female Students: A Case Study of Qassim University
}

\author{
Huda Sulieman Alqunayeer ${ }^{1, *} \&$ Sadia Zamir $^{1}$ \\ ${ }^{1}$ Qassim University, Al-Qassim, Kingdom of Saudi Arabia \\ *Correspondence: Qassim University, Al-Qassim, Kingdom of Saudi Arabia. Tel: 966-504-889-474. E-mail: \\ alqunayeer@hotmail.com, sadia.zamir@hotmail.com
}

Received: January 23, 2016

Accepted: March 8, 2016 Online Published: April 24, 2016

doi:10.5430/jct.v5n1p87

URL: http://dx.doi.org/10.5430/jct.v5n1p87

\begin{abstract}
This research study analyzes the target needs of EFL female Saudi students to choose EFL as their specialization. The population of the research is the female students enrolled in Bachelors in English program, at the Department of English Language and Translation, Qassim University Saudi Arabia. Adapting the Hutchinson And Waters model of Needs Analysis, the study covers the Target needs( i.e. Necessities, Lacks and Wants) and the Learning needs. It aims to suggest certain amendments in the curriculum on the basis of needs analysis. The sample for study consisted of 150 students, the data was collected through questionnaire and analyzed by using SPSS. Overall assessment of the data shows that the learners show their weakness in oral skills i.e. Listening and Speaking as compared to literary skills i.e. Reading and Writing. Students have shown their preference for the incorporation of practical activities and media based teaching material in their syllabus.
\end{abstract}

Keywords: needs analysis; EFL; target needs; necessities; lacks; wants; learning needs

\section{Introduction}

Needs analysis (NA) (also known as needs assessment) has been considered as an essential part of the curriculum development and review and plays a key part in the process of designing and carrying out any language course, whether it be English for Specific Purposes (ESP) or General English course (GE). The centrality of needs analysis has been recognized by several scholars and authors (Munby, 1978; Richterich and Chancerel, 1987; Hutchinson and Waters, 1987; Brindley, 1989; Dudley-Evans and St. John, 1998; Iwai et al. 1999; Hamp-Lyons, 2001; Finney, 2002).

The insertion of needs analysis in second language curriculum development began in the 1960's as language programs started emphasizing English for Specific Purposes (ESP) instruction. This ESP needs analysis focuses on collecting detailed language needs for vocational, academic and other purposes. Needs analysis has been an indispensible step not only in curriculum development but also in selection and evaluation of teaching activities in language teaching. Also, the importance of carrying out a needs analysis for developing English for Academic purposes (EAP) tests is emphasized by Fulcher (1999) and McDonough (1984).

The present study focuses on conducting linguistic needs analysis of the Bachelors level students of English language department at 'Qassim university, in the Al-Qassim province of the central region of Saudi Arabia.

\subsection{Research Questions}

The proposed study focuses on the following research questions:

1. What are the Target English language needs of the learners in the Bachelors in English Language program?

a. What are their necessities?

b. What are their wants?

c. What are their lacks?

2. What are the learning needs of the graduate students?

a. What is their preferred style of learning? 
b. What are the appropriate teaching methods for them?

\subsection{Significance of the Study}

The study will serve as a guide line for the curriculum designers and teaching practitioners, and will be helpful in making them bring out much better output from the learners, once they are clear about the objectives of their teaching practice. The findings of the study will be a practical help for the syllabus designers for the review of existing Bachelors level syllabus and will be useful in bringing modifications and revisions of the course in accordance with learners' target and learner needs.

\subsection{Rationale of the Study}

The requirement of the needs analysis originates from the fact that, the Four years Bachelors program in English Language and Translation has been shifted from annual system to semester system, in 2010, which comprises of eight levels. Besides, a new scheme of study has also been implemented. The teachers do not seem to be satisfied with the new developments, as they often complaint about the discrepancy in the course syllabus and think the changes are not appropriate for the students' language needs. Also, there was felt discontentment on behalf of students as they found some of the courses unrelated to their needs. So, these two major changes in the system of education and the dissatisfaction on the part of teaching professionals and students instigated the researcher to conduct an authentic needs analysis for the implementation of necessary amendments in the existing syllabus of English Language Department.

\subsection{Literature Review}

Many people have attempted to define the term Needs analysis, which helps in understanding its various dimensions. According to Iwai et al. (1999), the term needs analysis generally refers to the activities that are involved in collecting information that will serve as the basis for developing a curriculum that will meet the needs of a particular group of students. Brindely (1984) provides a wider definition of the term need, it is sometimes used to refer to wants, desires, demands, expectations, motivations, lacks, constraints, and requirements. The importance of this wider concept of needs is highlighted by the possible conflict that can arise when the curriculum and the students' beliefs and assumptions are not the same.

Hutchinson \& Waters (1992) believe that if learners, sponsors, and teachers know why learners need English, that awareness will have an influence on what will be accepted as reasonable content in the language course and what potential can be exploited...". In his state-of-the-art article, West (1994) gives a thorough overview of needs analysis in language teaching, including its history, theoretical basis, approaches to needs analysis, etc.

The systematic curriculum development model proposed by Brown (1995) regards needs analysis as the first element of Brown's curriculum approach. But he also makes needs analysis a continuous and permanent feature of curriculum revision, he points out that "....needs are not absolute, that is, once they are identified, they continually need to be examined for validity to ensure that they remain real needs for the students involved." This makes it clear that English language programs necessitate needs analysis as an element of routine revision of its curriculum. The curriculum revision becomes a necessity as the curriculum developed at the beginning of a program may not deal adequately with the changes happened over a period of time.

According to Hutchinson and Waters (1987), needs analysis originated from the field of ESP, however, Hutchinson and Waters refute the idea that in general English needs cannot be specified and argue that there should not be any difference between ESP and general English (GE) as far as needs analysis is concerned. They state that: "It is often argued that the needs of the general English learner, for example the schoolchild, are not specifiable. ... In fact, this is the weakest of all arguments, because it is always possible to specify needs, even if it is only the need to pass the exam at the end of the school year. There is always an identifiable need of some sort. What distinguishes ESP from General English is not the existence of a need as such but rather an awareness of the need" (Hutchinson \& Waters 1987).

The model adapted for this study, "A Learning Centered Approach" focuses on the learners needs as the name itself suggests. The learners' Needs split into two parts i.e. target needs and learning needs. Target needs comprise of necessities, wants and lacks. Whereas, learning needs consist of social and educational background, preferred teaching and learning style, attitude towards leaning.

This model has been selected as this is a comprehensive model covering various factors overlapping in other models discussed previously in this section 
First of all, it makes the basic distinction made between Target needs and learning needs. Target needs are defined as, what the learners need to do in target situation, whereas learning needs includes a list of information about their socio-cultural background, learning background, gender, age, background knowledge of English, attitudes towards English and culture of English speaking countries, appropriate or ineffective teaching and learning methods. The learning needs analysis will generate the students profile giving the age, gender, social and academic background, their attitudes towards English language and culture.

Then, target needs are further categorized into necessities, lacks and wants. Target needs will be identified by inquiring into their Necessities (the needs of the target situation/ learning goals), Lacks (the gap between existing proficiency and the target proficiency) and wants (learners own concept of learning, their preferred teaching content, teaching aid and learning style etc.)

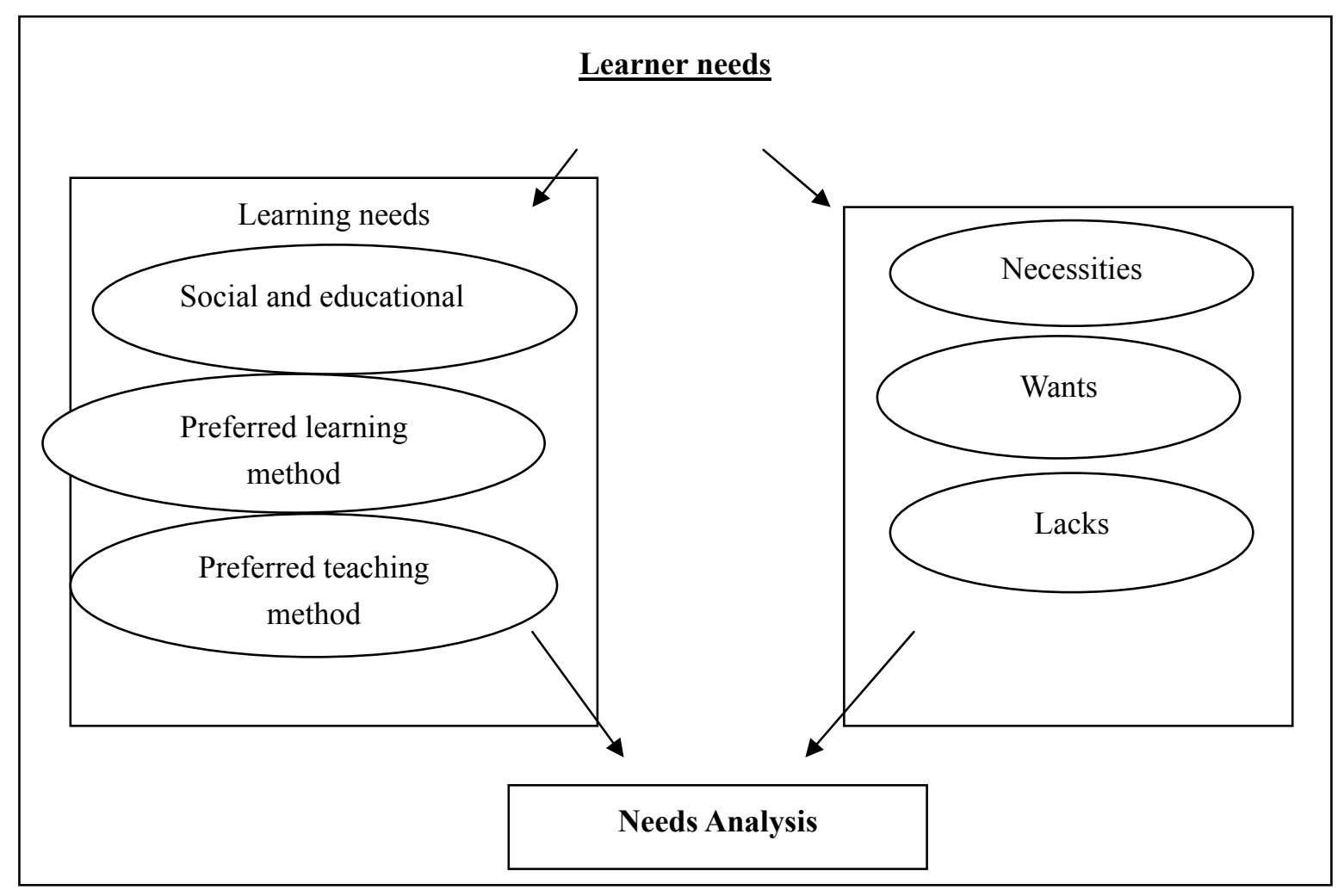

Figure 1. Theoretical Framework of Hutchison and Waters (1987)

Hutchinson \& Waters (1987) argue that other approaches give too much attention to language needs, whereas more attention should be given to how learners learn. They advocate that a learning needs approach is the finest means to pass on learners from the starting point to the target situation. It gives a comprehensive approach to the learners needs as it offers two focus areas: target needs and learning needs. Target needs are defined as what the learner needs to do in the target situation. They are broken down into three categories: necessities, wants and lacks. Necessities are considered to be "what the learner has to know in order to function effectively in the target situation". Wants are described as "what the learners think they need. Lacks are defined as the gaps between what the learner knows and the necessities. The second focus in this approach is on learning needs, referring to numerous factors, including who the learners are, their socio-cultural background, learning background, age, gender, background knowledge of specialized contents, background knowledge of English attitudes towards English, attitudes towards cultures of the English speaking world and studying English. Learner needs also involve Teaching and learning styles with which the learners are familiar, Appropriate or ineffective teaching and learning methods, Knowledge of specialized contents that teachers should have and suitable instruction materials and study location.

The following study was conducted to analyze the General English language needs of the Graduate level students as the literature review clearly indicates that there is a considerable dearth of NA in the field of general purposes English course in Saudi Arabian context. As discussed earlier in this chapter that Hutchinson and Waters establish 
that General English Courses also possess some specific needs that are to be analyzed, so an ESP model can be used to specify the needs of a General English course. For this purpose, the model given by Hutchinson and Waters has been adapted in the present study. The major contribution of this model is that it provides approach to the learners' needs more specifically to target and learning needs.

\section{Research Design}

This research is a case study that has been conducted to analyze the needs of EFL Bachelors level students of Qassim University. For random sampling, the researcher has selected 150 samples randomly from the students belonging to various semesters i.e. from 1 st semester to $4^{\text {th }}$ semester. The major tool that is used to collect data was questionnaires.

The framework used for the questionnaire was inspired from the Hutchison and Waters model of Need analysis. The questionnaire covers all aspects of research questions and the items of the questionnaire have been adapted from three sources:

i. Items concerning 'Necessities' have been adapted from Balint (2004) measured on Likert scale ranging from strongly disagree to strongly agree.

ii. Items inquiring about 'Wants' and 'Lacks' have been adapted from Dar (2009) measured on Likert scale ranging from strongly disagree to strongly agree.

iii. Queries catering for 'Learning Needs' have been adapted from Li Li (2010) measured on Likert scale ranging from strongly disagree to strongly agree.

A questionnaire was adapted to conduct needs analysis of the Bachelors level English language learners at Qassim University. The items of the questionnaire were analyzed by using Simple Frequency Distribution Method. The researcher made use of SPSS version 16 for analyzing the responses from the questionnaires. These research findings will help to generate the future career plans for learners of linguistics. It also evaluates their future need preferences within the field of linguistics.

\section{Data Analysis}

Research Question No. 1: What are the Target English languages needs of the learners in the Bachelors in English Language Program?

1a.1) Necessities: in terms of reasons to study English.

i) I have a goal to study abroad in the future.

According to the figure $2.1,69 \%$ of the learners agree to the statement that they are studying English because they want to go abroad for study, while $12.7 \%$ of learners have disagreed to the statement.

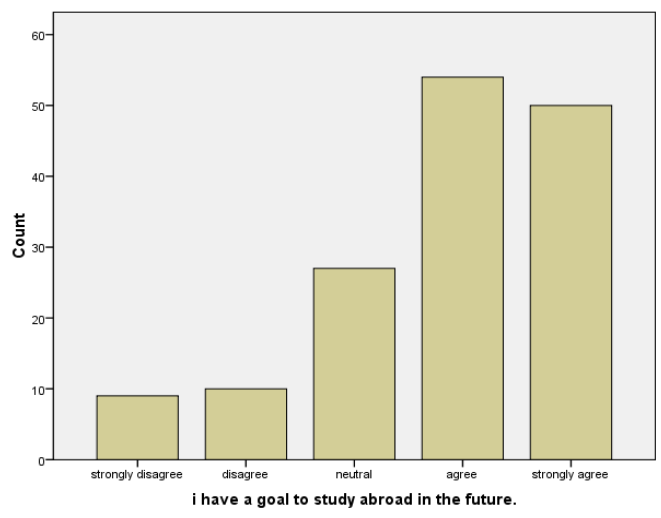

Figure 2.1. Study Abroad 
ii) Learning English is a challenge that I really enjoy.

From the figure 2.2, it is clear that majority of the respondents $(70 \%)$ take learning English as challenge that they really enjoy. Whereas, $(10 \%)$ respondents disagree to the statement that they enjoy English as challenge.

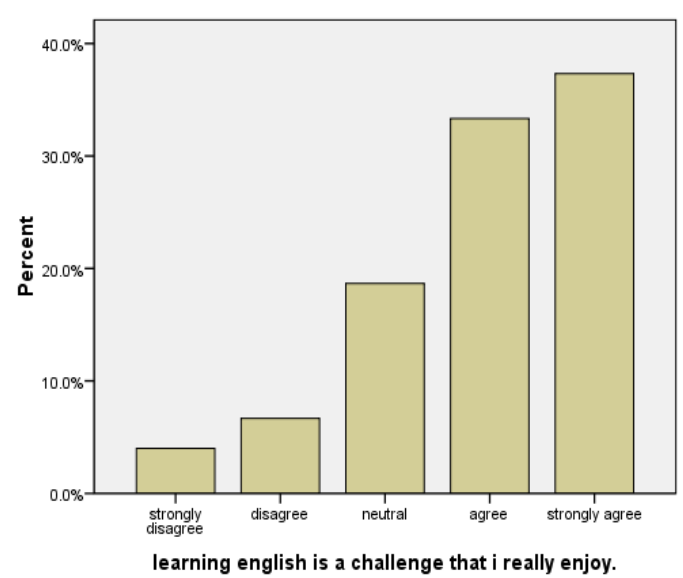

Figure 2.2. Learning as Challenge

iii) I want to learn English to be more educated.

The Figure 2.3, shows that majority of the respondents $(80 \%)$ are learning English to be more educated. $12.6 \%$ of respondents have shown disagreement over it.

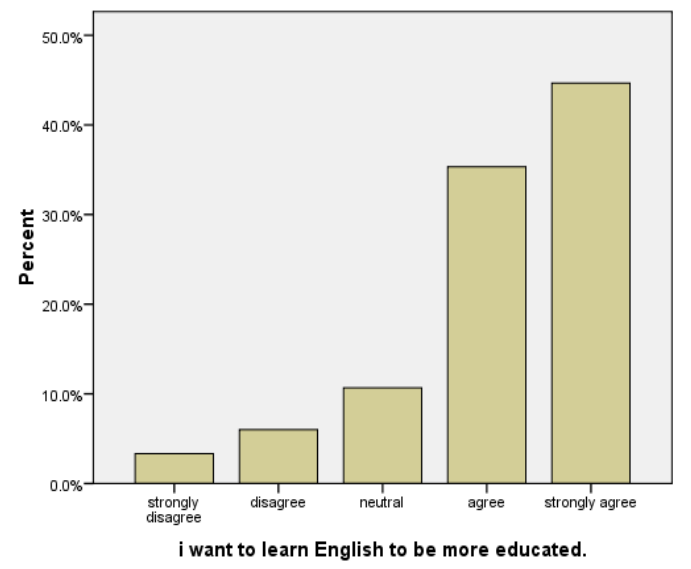

Figure 2.3. Learning for Education

iv) I believe learning English is important to get good job after graduating from a university.

The results of this query (Figure 2.4) indicate that majority of the respondents i.e. $(84 \%)$ believe learning English is important to get good job after graduating from a university. Whereas, only 5\% respondents have not shown agreement to the statement that English is necessary for good job.

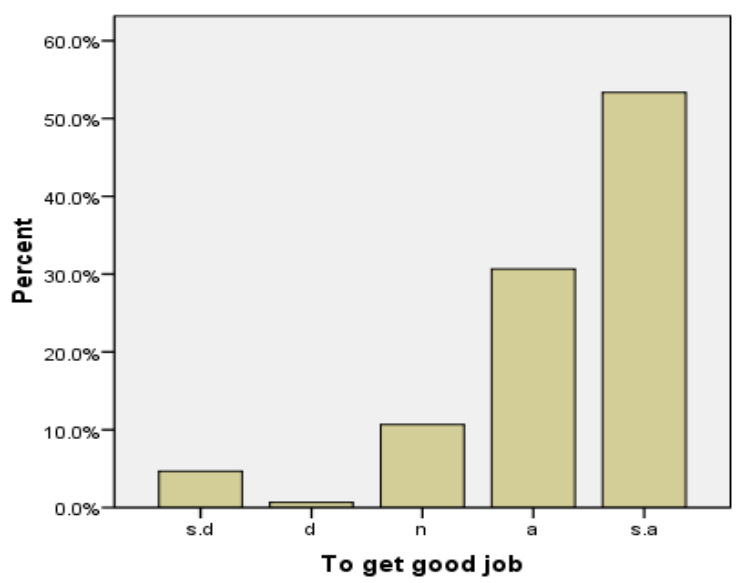

Figure 2.4. To Get Job 
v) I have great interest in English.

From the Figure 2.5, 71\% of the total learners have shown great interest in English. While only $8 \%$ respondents have not shown their interest in English.

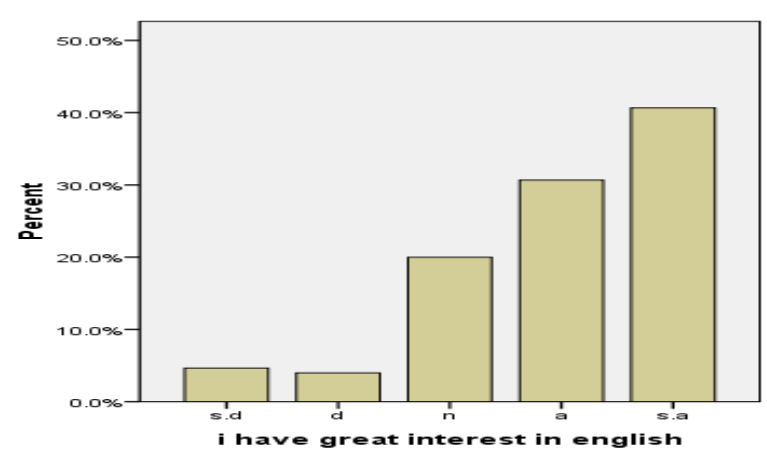

Figure 2.5. Interest in English

1) Necessities: in terms of useful English language skills in future ?

i) Reading skill

Figure 2.6 shows that $67 \%$ learners agree to the usefulness of reading skills in future. Whereas, only (9\%) respondents don't take it as useful skill for future.

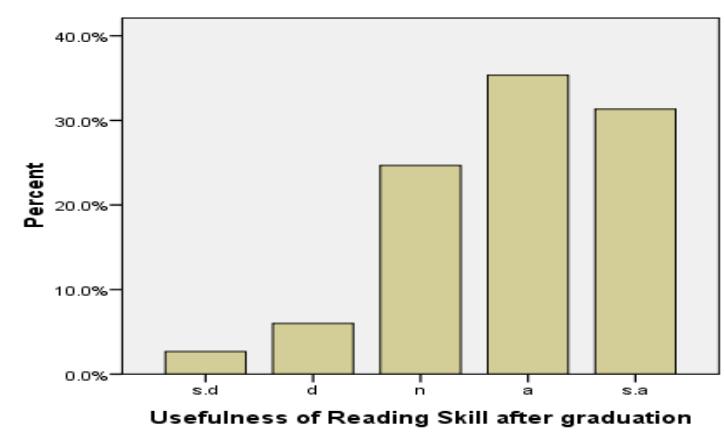

ii) Listening skill

Figure 2.6. Reading after Graduation

From the Figure 2.7, it is evident that $69 \%$ of the respondents agreed to the usefulness of listening skills in future. Whereas, $12 \%$ respondents don't take it as useful skill for future.

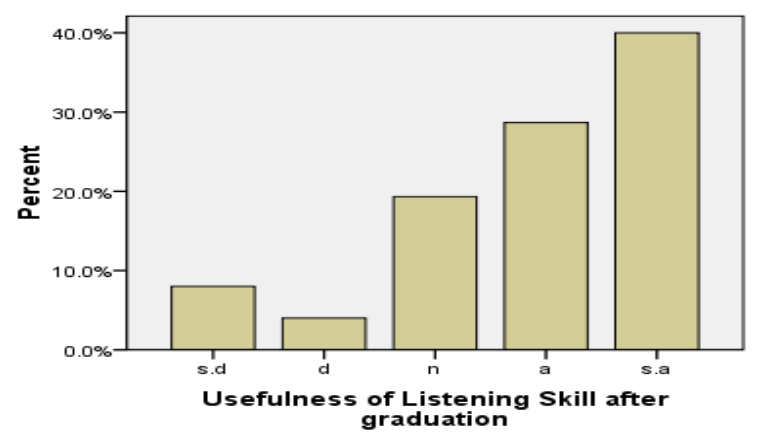

Figure 2.7. Listening after Graduation 
iii) Speaking skill

The Figure 2.8 indicates that majority of the respondents i.e. $85 \%$ agreed to the usefulness of speaking skills in future. Whereas, 8\% respondents don't regard it as useful skill for future.

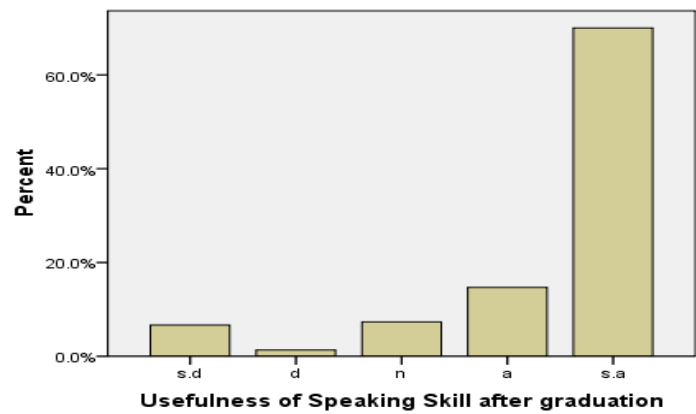

Figure 2.8. Speaking after Graduation
Figure 2.9 shows that $70 \%$ of the learners agree to the usefulness of writing skills in future. Whereas, only $5.3 \%$ respondents don't take it as useful skill for future.

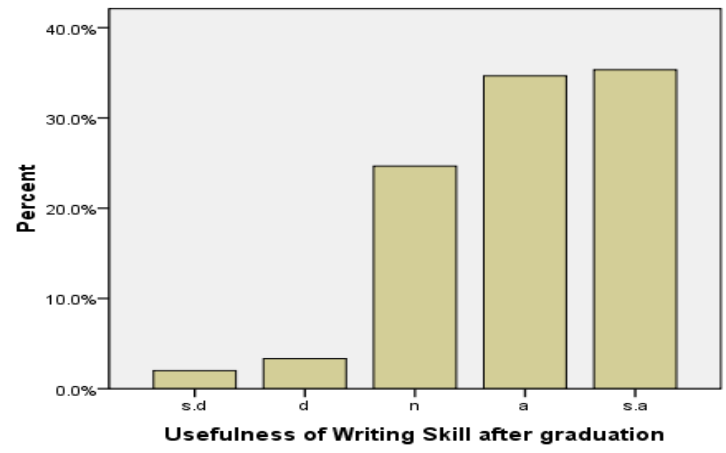

Figure 2.9. Writing after Graduation

\section{Research Question No. 1b}

What are the targets English language needs of the learners in the Bachelors in English Language Program in terms of wants?

\section{1b.2 Wants: Skills to develop through this course}
i)
Understanding speech

In Figure 2.10, the result shows that $63 \%$ of the respondents want to develop speech understanding through this course. Whereas, only (9\%) respondents don't consider it necessary.

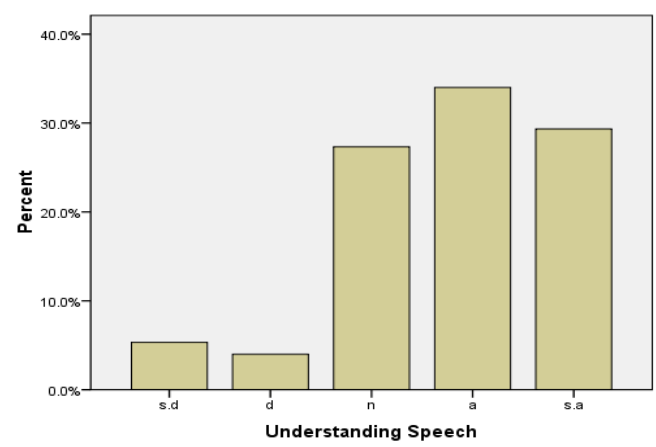

Figure 2.10. Understanding Speech 
ii) Understanding written materials

From the Figure 2.11, it is clear 59\% of the learners want to develop written materials understanding through this course. Whereas, only $9 \%$ of them don't consider it necessary.

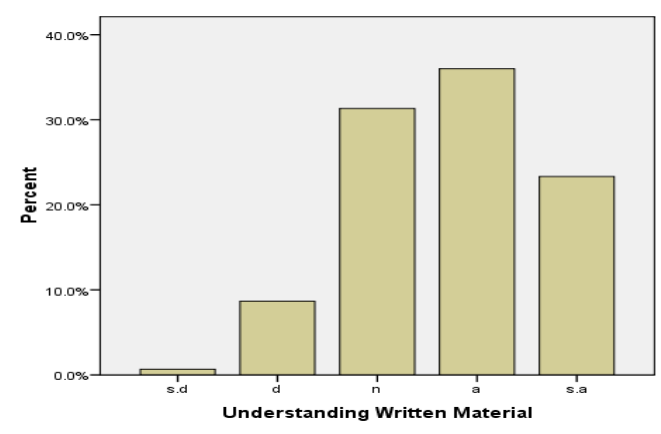

Figure 2.11. Understanding Written Materials

iii) Speaking

From the Figure 2.12, it is evident that majority of the respondents i.e. $77 \%$ want to develop speaking skills through this course. Whereas, only $7 \%$ have disagreed to the statement.

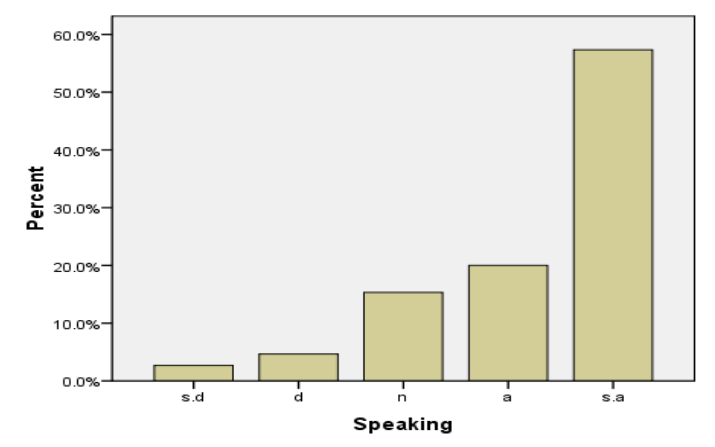

Figure 2.12. Developing Speaking

iv) Writing

Figure 2.13, shows that $65 \%$ of the learners want to enhance their writing skills through this course. Whereas, only $9 \%$ respondents think that it is needed.

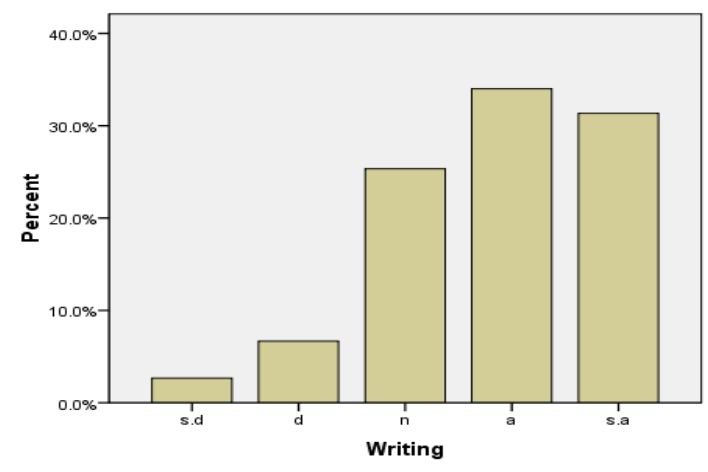

Figure 2.13. Developing Writing 
v) Translation skills

From the Figure 2.14, it is obvious that majority of the respondents $75 \%$ want to develop translation skills through this course. Whereas, only $7 \%$ respondents don't consider it necessary.

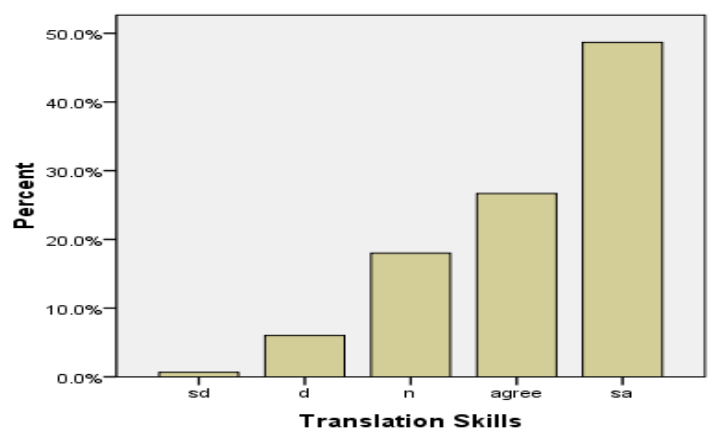

Figure 2.14. Developing Translation Skills

\section{Research Question No. 1c}

What are the targets English language needs of the learners in the Bachelors in English Language Program in terms of lacks?

Lacks: whenever I use English language, I feel difficulty in:

i) Speaking fluently

The result in Figure 2.15, indicates that most of the students i.e. $62 \%$ face difficulty in speaking fluently. Whereas, $9 \%$ respondents never felt any problem.

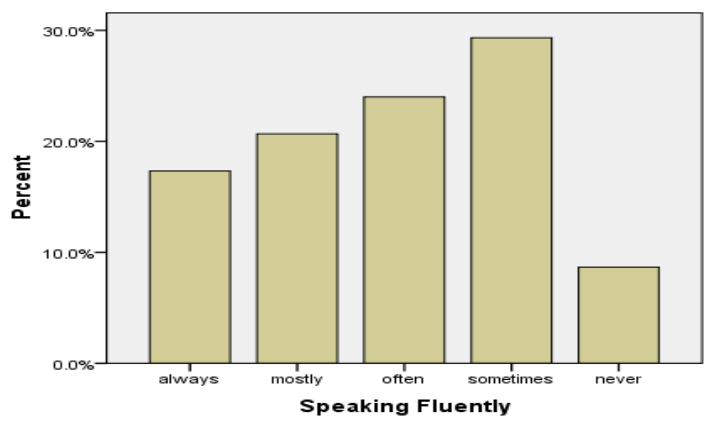

Figure 2.15. Speaking Fluently

ii) Using correct grammatical sentences

According to figure 2.16, 63\% of the learners feel difficulty in using correct grammar. Whereas, only 5\% respondents don't feel any problem.

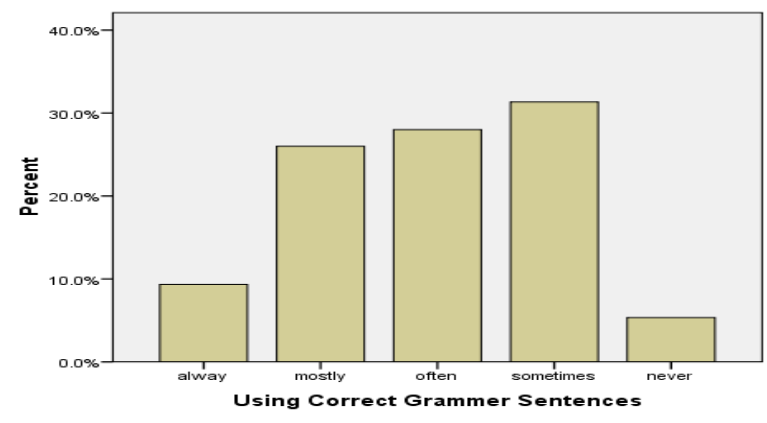

Figure 2.16. Difficulty in Using Correct Grammar 
iii) Pronunciation

The figure 2.17 shows that most of the respondents i.e. $52 \%$ feel difficulty in pronunciation. Whereas, $13 \%$ respondents don't feel any problem.

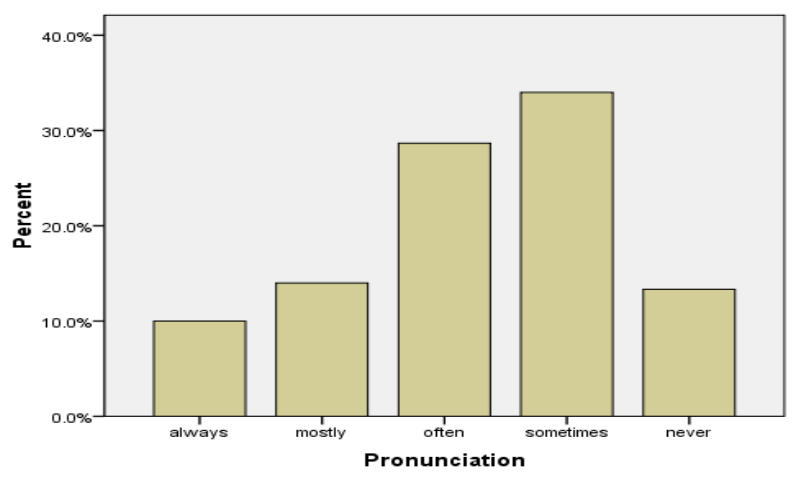

Figure 2.17. Difficulty in Pronunciation

iv) Confidence

From the Figure 2.18, it is evident that majority of the respondents $63 \%$ feel difficulty in using English with confidence. Whereas, only $8 \%$ respondents don't feel any problem in confidence.

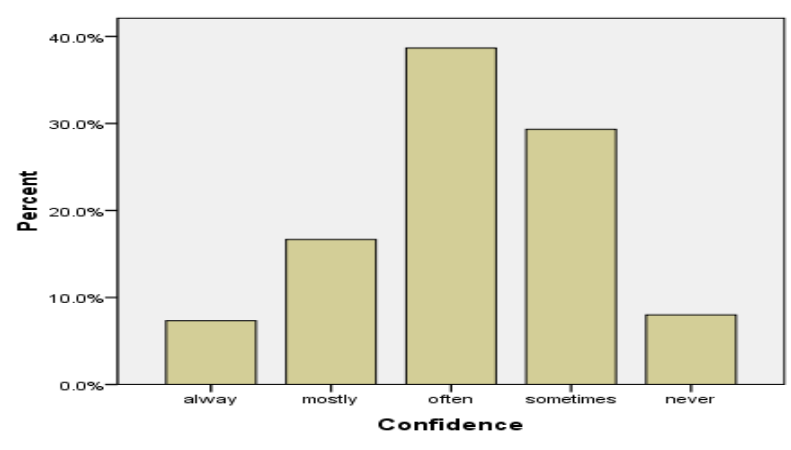

Figure 2.18. Difficulty in Confidence

v) Understanding English

According to this figure $2.19,50 \%$ of the learners feel difficulty in understanding English. Whereas, only $20 \%$ respondents don't feel any problem.

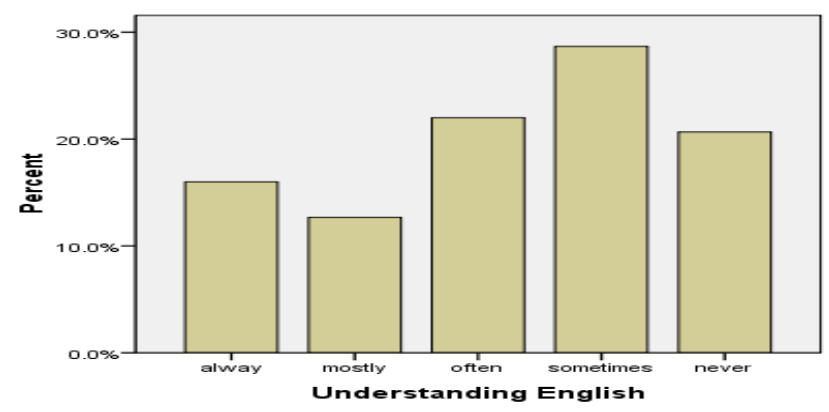

Figure 2.19. Difficulty in Understanding English 


\section{vi) Reading}

The results of this figure 2.20 indicates that only $40 \%$ of the learners feel any problem in reading English. (60\%) do not feel any difficulty in reading English.

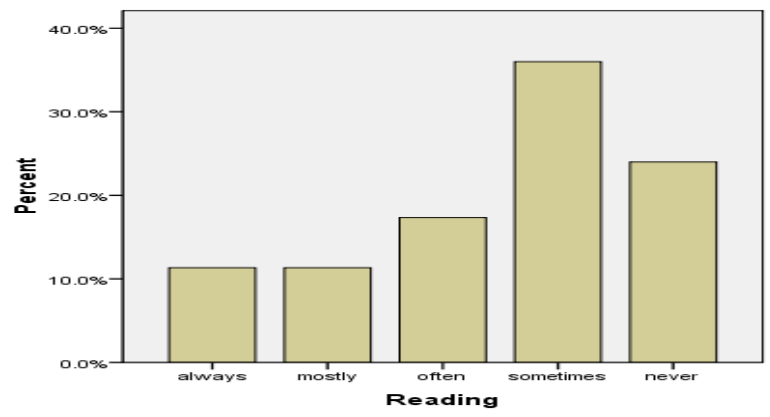

Figure 2.20. Difficulty in Reading
The figure 2.21 indicates that $51 \%$ of the learners show agreement that they feel difficulty in writing English. Whereas, $49 \%$ respondents don't feel any problem. So the results is somewhat neutral.

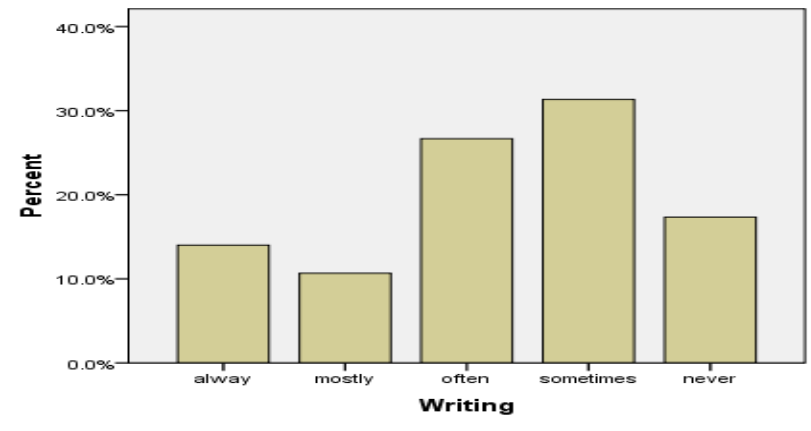

Figure 2.21. Difficulty in Writing

viii) Learning new words (vocabulary)

From the Figure 2.22, it is clear that most of the respondents (54\%) show agreement that learning new words i.e.(vocabulary) seems difficult to them. although, only $14 \%$ respondents don't feel any problem.

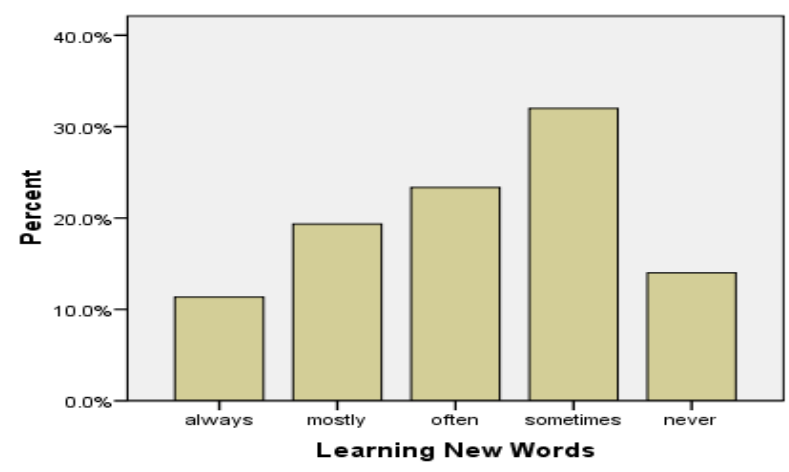

Figure 2.22. Difficulty in Learning Vocabulary 
ix) Spellings

From the Figure 2.23, it is evident that majority of the respondents $(67 \%)$ have shown that they face problems in learning spellings. Whereas, only $8 \%$ respondents don't feel any problem.

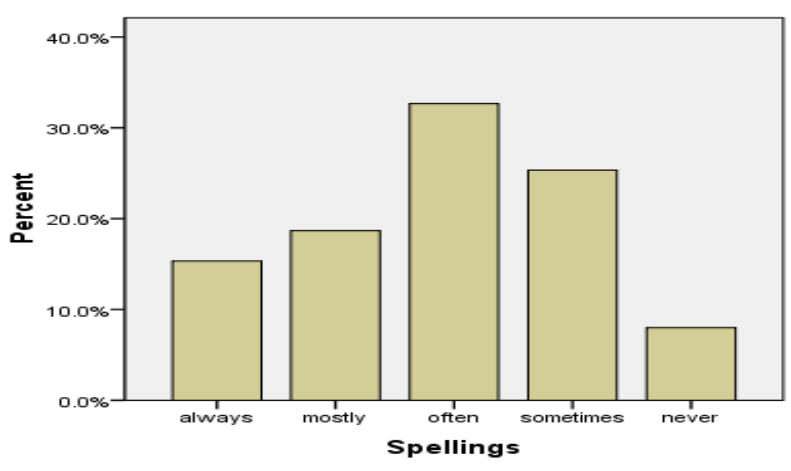

Figure 2.23. Difficulty in Spellings

1c.2 Lacks: in terms of skills

i) Reading skills

Figure 2.24, makes it obvious that $57 \%$ of the learners consider themselves good at reading skills. Whereas, very few i.e. $07 \%$ respondents take themselves as poor in this skill.

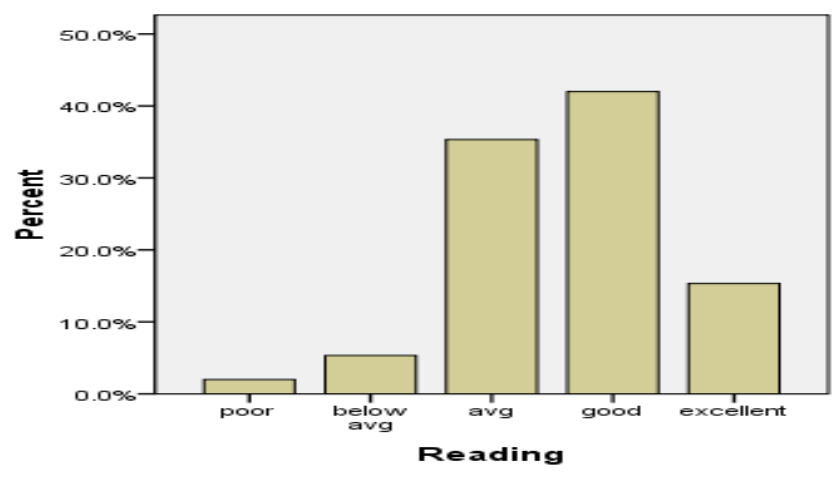

Figure 2.24. Proficiency in Reading

\section{ii) Writing skills}

From the Figure 2.25, it is evident that $52 \%$ of the learners rate their writing skills as good. Whereas, $10 \%$ respondents rate them as below average.

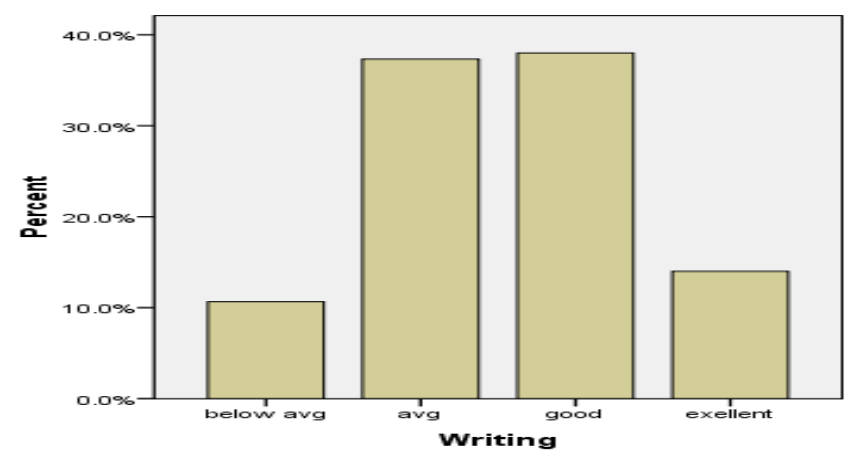

Figure 2.25. Proficiency in Writing 
iii) Listening skills

This figure 2.26 indicates that $33 \%$ rate their listening skills as average. And $46 \%$ regard themselves as good at it. Whereas, (21\%) respondents rate them as below average.

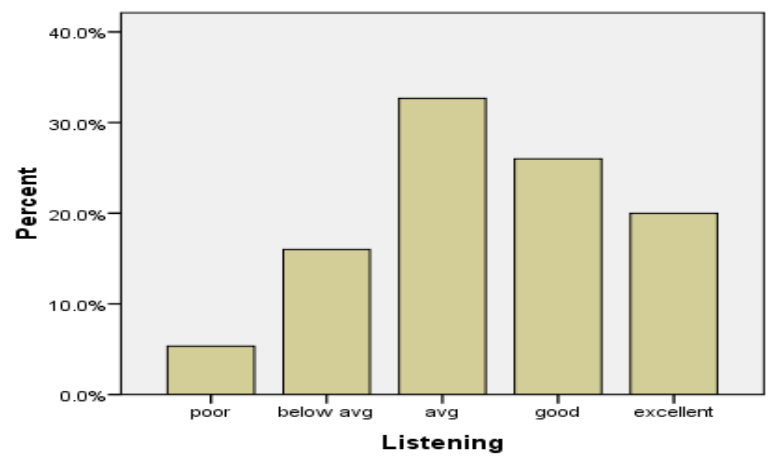

Figure 2.26. Proficiency in Listening

Figure 2.27 , manifests that $38 \%$ of the learners rate their Speaking skills as average, whereas $45 \%$ of the learners consider themselves good at speaking skills. Whereas, $17 \%$ respondents rate them as below average.

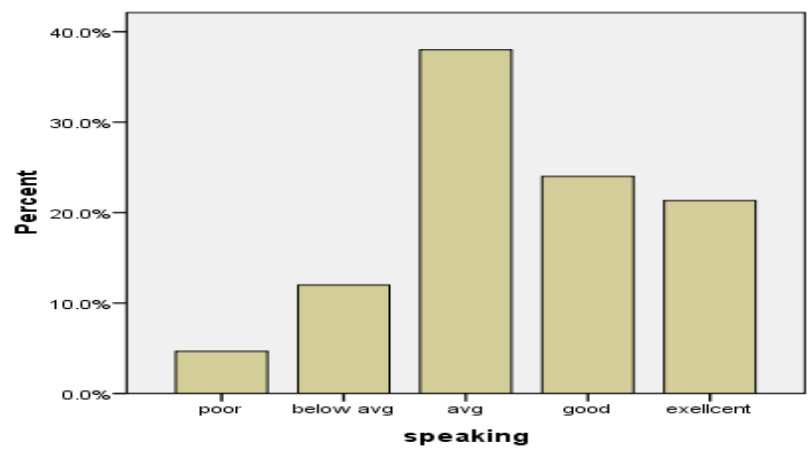

Figure 2.27. Proficiency in Speaking

Research Question No. 2: What are the learning needs of the graduate students?

2.1) What is learners preferred style of learning.

a) How do you improve your English ability while learning? The figure shows that majority of the students i.e. 47\% want to improve their English ability by themselves. While the other prominent group wants to take part in English language learning activities.

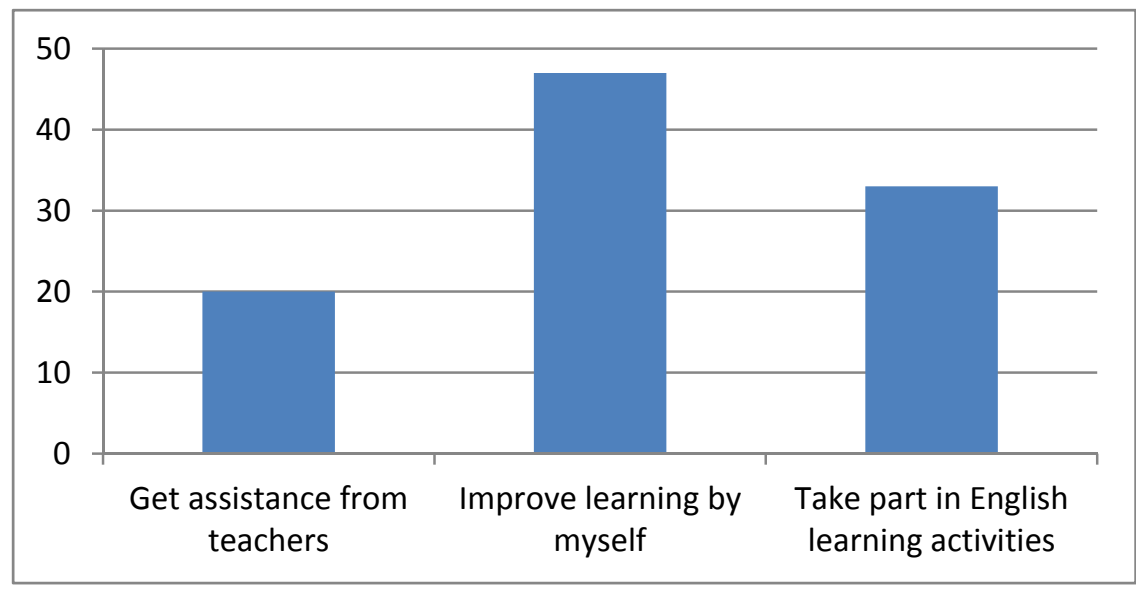

Figure 3.1. How Do You Improve English Language Ability While Learning? 
b) I prefer the following classroom activities

Figure 3.2 shows that majority of the students i.e. $38 \%$ appreciate conversation as classroom activities, whereas other prominent activities include photos and movies.

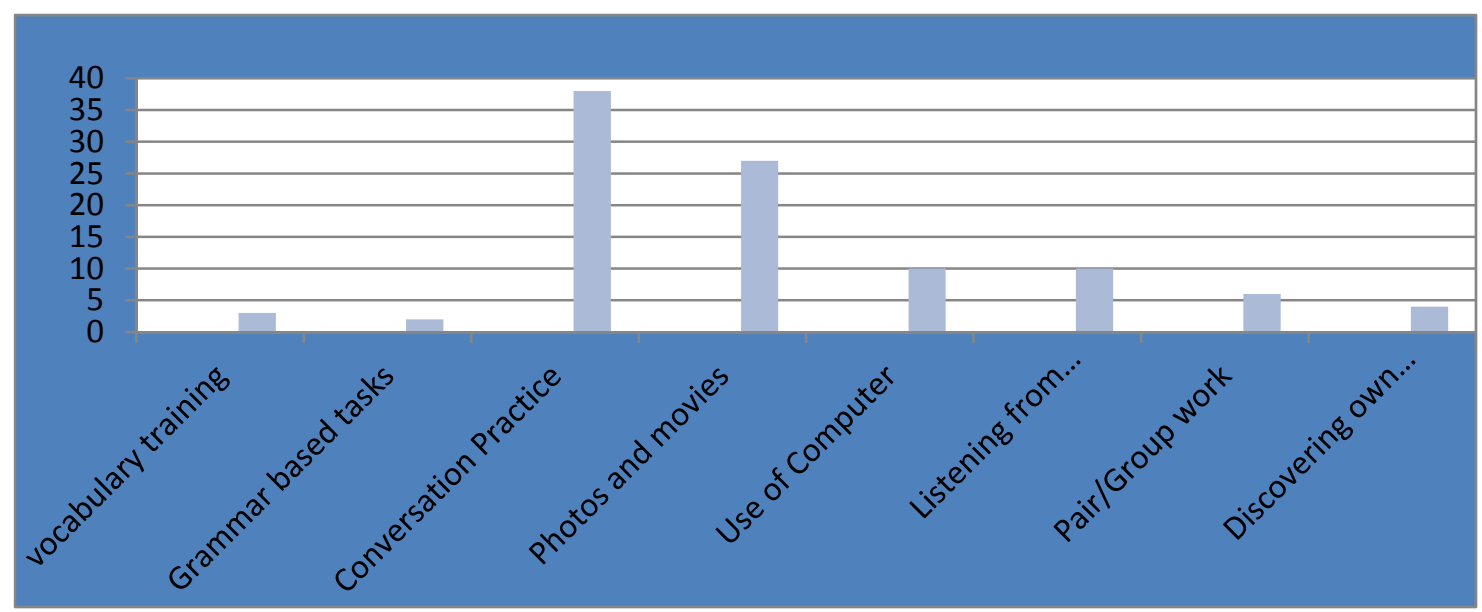

Figure 3.2. Preferred Classroom Activities

2.2) What are the appropriate teaching methods for them?

a) What are your favorite classroom activities?

Figure 3.3 shows that students i.e 30\% prefer personal speech/ presentationa and group discussion as favorite classroom activities.

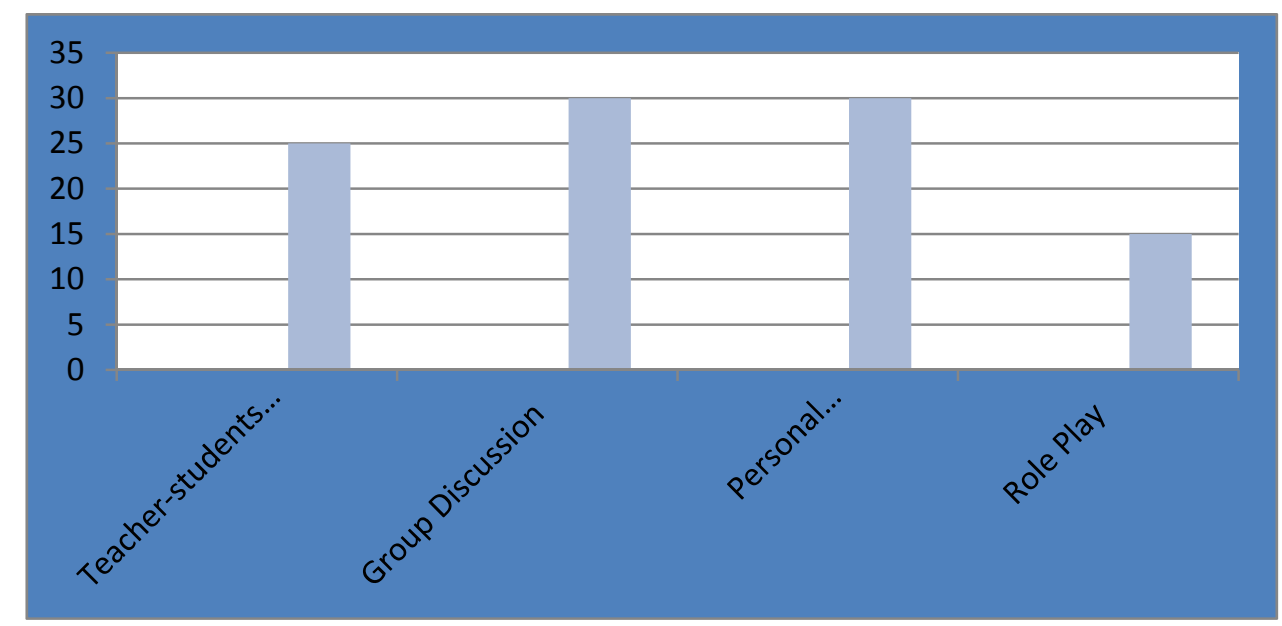

Figure 3.3. Favorite Classroom Activities

b) what are your favorite after class activities?

Figure 3.4 shows that majority of the students i.e. 38\% prefer Watching English movies as the favorite after class activity. 


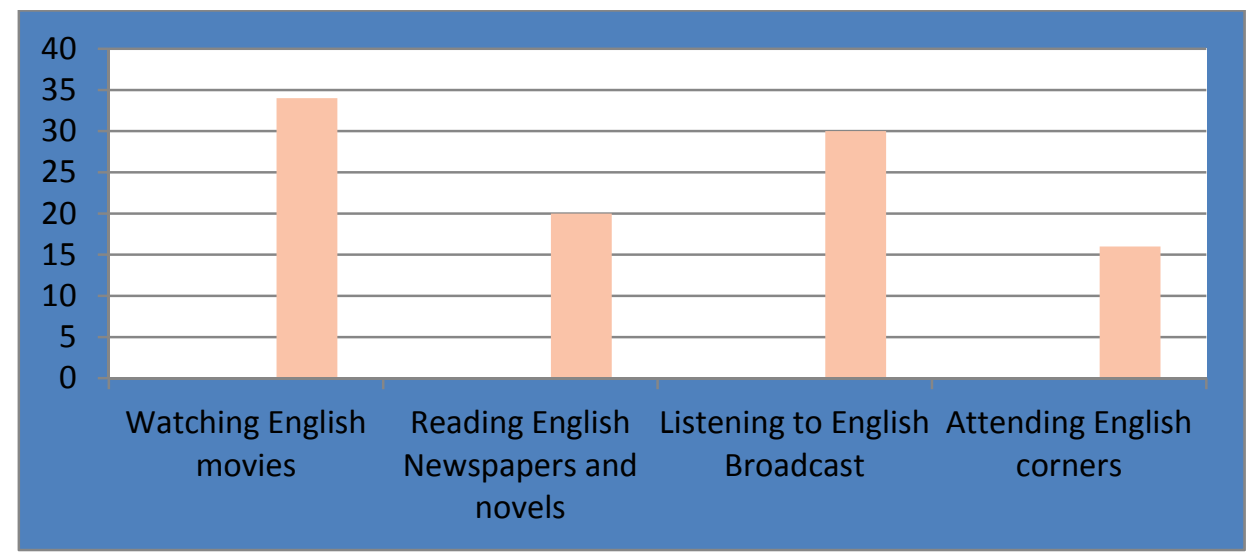

Figure 3.4. Favorite after-Class Activities

\section{Discussion}

Findings of the study conducted in English Language department, Qassim University, Saudi Arabia for assessing the Needs of English language learners, are as follows:

The students' profile of English language shows that out of 12 years of education at school, English is taught for 7 years as it starts from grade VI, rather than grade I, hence the learners' start learning English at the age of 12. Besides, in Saudi Arabia, English is a foreign language and not a second language that is why students get little or no exposure to this language in their immediate environment for instance family, relatives etc., Students/ learners are deprived of the opportunity to communicate in English in real life situations, consequently encounter more problems in using English as a language of communication.

Information collected indicates that very few of the learners have had the experience of living in an English speaking country. Consequently, "English" becomes an intimidating and formidable subject for any potential student.

Concerning students' decision of selecting Bachelors in English, it is observed that they regard English as an exalted field. Most of the students want to improve their general grasp of the language in order to develop effective communication with the outside world, as they regard inefficiency in using English language as a main hindrance in the way of their prosperity and progress. Their main aim to study English is general communication but when asked about their future, many students see their careers as teachers, interpreters or translator, as these professions have greater scope in a country like Saudi Arabia where English language is not a second language but a Foreign language. Owing to this reason, most of the students want to pursue Linguistic field in English rather than literature or any other field.

Queries about the course outline and teaching approach revealed that majority of the students are satisfied with the teachers' teaching approach but they have shown an average satisfaction level towards the existing English course outline. From the data it is concluded that majority of the learners are studying this course because they want to improve their communication skills and also consider these skills necessary to get good jobs in future after graduating from the university. They consider speaking as the most valuable skill for their future prospects. For that reason, they give more importance to the practice of speaking skill during the course. They want to be able to speak English confidently with fluency and without any grammatical errors. Second preference is given to the Listening skill as they think that they need to understand the native accent in order to be fluent in communication and then comes Writing Skills and Reading becomes the last preference.

Moreover, students do not see a gradual progression in the scheme of study offered to them. They feel there is no transition phase when they move to higher levels. Some subjects have connection neither with the previously taught subjects nor with the subjects to be taught at the upcoming levels. e.g. Cognitive and Metacognitive Strategies of Language learning at $3^{\text {rd }}$ Semester. Study skills at $1^{\text {st }}$ semester. International tests at $2^{\text {nd }}$ semester etc. Pronunciation is focused on only in $1^{\text {st }}$ semester and there is no reinforcement in the subsequent semesters. Theoretical aspects are dealt with in Phonetics and Phonology at the $5^{\text {th }}$ semester. Introduction to literature is taught at $4^{\text {th }}$ semester, and seems to have little value as no literary subjects are offered in the upcoming semesters. Listening and speaking is focused in the first three semesters if it is continued in the next semester also it may yield better result and help students in improving their proficiency level. Students' dissatisfaction with the overall pattern of the scheme of study and inability to see the smooth transition and progression at the various phases of their study plan has a negative 
impact. Consequently, their performance is affected and they are unable to achieve the desired level of proficiency. It is recommended that the feedback from the students at the end of term be given due importance and considered while revising curriculum. If the students' interest, needs and satisfaction level is taken into account, it will enhance their productivity.

Respondents have also shown preference for in-class communicative activities like group discussion, teacher-student interaction and role plays. After class activities include watching English movies and listening to English broadcast which is essential for their ear training in order to enable them to understand the native speakers besides improving their own accent. Respondents find the traditional black/white board use ineffective and want the methods that address the multiple intelligences. Audio-visual materials are strongly recommended to help auditory and visual learners and kinesthetic to reinforce and instill the learnt material. They also favored the technology-based teaching along with the use of authentic materials for their originality.

Another interesting fact that has been highlighted by the study is that learners' majority rate self regulated learning methods as one of the regular ways of improving their English proficiency. This provides an evidence that they aspire to become independent learners and they want the teacher as a facilitator, a guide and a moderator to monitor the class activities. Hence they support student-centered teaching approach.

When asked to identify areas where they feel difficulty while using English language, they pointed out that the lack of confidence was the major factor hindering the use of language hence, they feel hesitation while communicating in English language. They suggested that their course should be revised and tailored to cater to their needs. Regarding the skills, majority of the learners rated themselves as below average in listening and speaking skills, and average in reading and writing skills. Overall assessment of the data confirms that the learners consider themselves weaker in oral skills i.e. Listening and Speaking as compared to literary skills i.e. Reading and Writing. Therefore, they demand more practice and focus on oral skills.

\section{Recommendations}

Following are the recommendations based on the research conducted, to be considered by the syllabus designers and curriculum developers.

1. Since the maximum number of learners have shown their interest in the field of linguistics and as the new scheme of study focuses more on the linguistic courses, it is strongly recommended that this emphasis should be maintained in the future.

2. It becomes mandatory that Speaking skills is given due importance in the syllabus and communicative activities be conducted in class to enhance students' talking time thus giving them sufficient practice to give them confidence in the language use ultimately improving their proficiency level in English language.

3. As majority of students want to get good jobs after their graduation so their curriculum should be tailored in accordance with their specified needs. The courses should be revised accordingly to prepare future teachers and translators.

4. It is evident from the data that learners find lack of confidence a major hindrance in the use of English language. In order to help learners overcome this problem it is recommended that activities like public speaking, making presentation, independent tasks and projects should be introduced as part of the syllabus both for in-class and after class activities thus making them confident autonomous learners.

5. Maximum utilization of audio visual aids can ensure higher motivation level of learners and involving them in tasks based on movies/ video clips especially based on real life situations can be of utmost importance as they can associate themselves with the content, hence, making their learning process as natural as possible.

6. In order to make students independent learners they need to acquire library skills but there are no time slots allocated for library consultation, students are neither motivated nor encouraged to visit library and consult reference books and other materials in order to get general and comprehensive understanding of linguistic concepts. The library is not well equipped to cater to the needs of language learners. No audio visual aids are available in the library. It is strongly recommended that simplified and abridged versions of English classics, children storybooks and magazines be made available in the library. It is also recommended that some time slots be allocated in the time table when students can go to the library and develop their library skills in the supervision of the teacher. 
7. Finally, the prevalent scheme of study needs to be extensively revised as it does not satisfy the target and learning needs of the learners. The revised curriculum should be learner centered and take learners' varied learning styles and multiple intelligences into account ultimately making them independent learners.

\section{References}

Balint, Martin. (2004). Assessing Students' Perceived Needs in a Need Analysis. Proceedings of the 9th conference of pan-pacific Association of applied linguistics.

Brindley, G. (1989). The role of needs analysis in adult ESL program design. In: Johnson, R .K. (Ed.), The second language curriculum (pp.63-78). Cambridge: Cambridge University press. http://dx.doi.org/10.1017/CBO9781139524520.007

Cohen, L., Manion, L., \& Morrison, K. (2000). Research Methods In Education (5th ed.). New York: Rout-ledge. http://dx.doi.org/10.4324/9780203224342

Cunningsworth, A. (1995). Choosing Your Coursebook. Oxford: Heinemann.

Dar, Maryam. (2009). Analyzing Target Needs of the students of Advance English Language Diploma: A Case Study of National University of Modern Languages, M. phil. Thesis. International Islamic University Islamabad.

Finney, D. (2002). The ELT curriculum: A flexible model for a changing world. In: Richards, J. C. \& Renandya, W. A. (Eds.). Methodology In Language Teaching: An Anthology Of Current Practice (pp. 69- 9). Cambridge: Cambridge University Press. http://dx.doi.org/10.1017/cbo9780511667190.012

Fultcher, G. (1999). Assessment In English For Academic Purposes: Putting Content Validity In Its Place. Applied Linguistics, 20(2), 221-236. http://dx.doi.org/10.1093/applin/20.2.221

Gilabert, R. (2005). Evaluating the use of multiple sources and methods in needs analysis: A case study of journalists in the autonomous community of Catalonia (Spain). In M.H. Long (Ed.), Second Language Needs Analysis (pp. 182-199). Cambridge: Cambridge University Press. http://dx.doi.org/10.1017/CBO9780511667299.007

Hamp-Lyons, L. (2001). English For Academic Purposes. In: Carter, R. and Nunan, D. (Eds.), The Cambridge Guide To Teaching English To Speakers Of Other Languages. (pp. 126-130). Cambridge: Cambridge University Press. http://dx.doi.org/10.1017/CBO9780511667206.019

Hutchinson, T., \& Waters, A. (1987). English for specific purposes: A learning-centered approach. Cambridge: Cambridge University Press. http://dx.doi.org/10.1017/CBO9780511733031

Iwai, T., Kondo, K., Limm, S. J. D., Ray, E. G., Shimizu, H., \& Brown, J. D. (1999). Japanese language needs analysis. Retrieved from http://www.nflrc.hawaii.edu/Networks/NW13/NW13.pdf

Johns, A. (1991). English For Specific Purposes: Its History And Contribution. In Celce-Murcia, M. (Ed.), Teaching English As A Second Or Foreign Language. (pp. 67-77). Boston, MA: Heinle \& Heinle.

Lambert, Craig. (2010). A Task Based Analysis: Putting Principles Into Practice. Language Teaching Research, 14(1), 99-112. http://dx.doi.org/10.1177/1362168809346520

Long, M.H. (2005a). Methodological Issues In Learner Needs Analysis. In M.H. Long (Ed.), Second Language Needs Analysis (pp. 19-76). Cambridge: Cambridge University Press. http://dx.doi.org/10.1017/CBO9780511667299.002

Long, M.H. (2005b). Overview: A Rationale For Needs Analysis And Needs Analysis Research. In M.H. Long (Ed.), Second language needs analysis. (pp. 1-16). Cambridge: Cambridge University Press. http://dx.doi.org/10.1017/CBO9780511667299.001

McDonough, J. (1984). ESP in Perspective: A Practical Guide. London: Colins ELT.

Munby, J. (1978). Communicative Syllabus Design. Cambridge: Cambridge University Press.

Nation, P. (2000). Designing And Improving A Language Course. Forum, 38, 2.

Richterich, R., \& Chancerel, J.-L. (1977). Identifying The Needs Of Adults Learning A Foreign Language. Oxford: Pergamon Press.

Robinson, P. (1991). ESP Today: A Practitioner's Guide. Prentice Hall. UK: Prentice Hall International (UK) Ltd.

Seedhouse, P. (1995). Needs Analysis and the General English Classroom. ELT Journal, 49(1), 59-65. 
http://dx.doi.org/10.1093/elt/49.1.59

Songhori, M.H. (2007). Introduction to Need analysis. English For Specific Purposes World, 4, 2008.

West, R. (1994). Needs Analysis In Language Teaching. Language Teaching, 27(1), 1-19. http://dx.doi.org/10.1017/S0261444800007527

West, R. (1998). ESP-State Of The Art. Retrieved from www.man.ac.uk/CELSE/esp/west.htm

Writing@ CSU Writing Guide: Case Studies, Definition and overview, Retrieved Jan 232013 from http://writing.colostate.edu/guides/pdfs/guide60.pdf 